\title{
OCENA ZALEŻNOŚCI POMIĘDZY SKŁADKĄ NA UBEZPIECZENIE WYPADKOWE A PROFILAKTYKĄ BHP W PRZEDSIĘBIORSTWACH PRZEMYSŁU SPOŻYWCZEGO
}

\author{
Anetta Zielińska \\ Katedra Zarządzania Uniwersytetu Jana Kochanowskiego w Kielcach, \\ Filia w Piotrkowie Trybunalskim \\ Kierownik Katedry: prof. dr hab. Sławomir Juszczyk
}

\begin{abstract}
Słowa kluczowe: regresja liniowa, składka na ubezpieczenie wypadkowe, kategoria ryzyka Key words: linear regression, accident insurance premium, risk category

S y n o p s i s. Artykuł dotyczy oceny związku między poziomem odprowadzanych składek na ubezpieczenie wypadkowe a poziomem kosztów na działalność profilaktyczną w zakresie bezpieczeństwa i higieny pracy, które nie obejmują kosztów tych składek, w przedsiębiorstwach spożywczych w województwie łódzkim. Oszacowane modele regresji liniowej kosztów na działalność profilaktyczną względem wysokości składki na ubezpieczenie wypadkowe wskazały istnienie dodatniej zależności między tymi zmiennymi.
\end{abstract}

\section{WPROWADZENIE}

Strategia Unii Europejskiej w zakresie ochrony zdrowia w miejscu pracy w dokumencie programowym informuje, że bezpieczeństwo i higiena pracy stanowią obecnie jeden z ważniejszych aspektów polityki Unii Europejskiej dotyczącej zatrudnienia i spraw społecznych zgodnie z art. 137 „Traktatu ustanawiającego Wspólnotę Europejską” [Dz.Urz. UE 2006 C 321E].

Problematyka występowania wypadków przy pracy jest ciągle aktualna. Mimo postępu technicznego i coraz lepszego przygotowania służb BHP do podejmowania działań służących ograniczeniu tych zjawisk, liczba wypadków przy pracy pozostaje ciągle na wysokim poziomie [Barwicka 2011, s. 1-3]. Zaistniałe wypadki przy pracy w przedsiębiorstwie bezpośrednio wpływają na wysokość składki na ubezpieczenie wypadkowe. Wynikają one głównie z nieprzestrzegania szeroko rozumianej kultury bezpieczeństwa pracy, czyli z nieprawidłowego - z punktu widzenia bezpieczeństwa i ochrony zdrowia - zachowania pracowników oraz ogólnie złej organizacji pracy [Ślawska 2006, s. 11-21].

Od wielu lat w zakładach pracy stosowane są różne rodzaje materialnych i moralnych zachęt do aktywnego uczestnictwa w kształtowaniu bezpiecznych warunków pracy. Istnieją także przepisy prawne określające odpowiedzialność dyscyplinarną, służbową oraz karną za nieprzestrzeganie przepisów BHP i niedopełnienie obowiązków w tym zakresie. Dotyczy to kierownictwa zakładów pracy oraz pracowników. Z dostępnej literatury przedmiotu 
wynika, że w różnych krajach zachęty adresowane do pracowników są finansowane bądź bezpośrednio przez pracodawców, bądź pośrednio przez instytucje ubezpieczeniowe.

Zakład Ubezpieczeń Społecznych przy obliczaniu składki na ubezpieczenie wypadkowe badanych przedsiębiorstw ustala kategorię ryzyka dla grupy działalności, kierując się następującymi wskaźnikami częstości [Rozporządzenie... Dz.U. nr 200, poz. 1692]:

- poszkodowanych w wypadkach przy pracy ogółem,

- poszkodowanych w wypadkach przy pracy - śmiertelnych i ciężkich,

- stwierdzonych chorób zawodowych,

- zatrudnionych w warunkach zagrożenia w razie przekroczenia najwyższych dopuszczalnych stężeń i natężeń czynników szkodliwych dla zdrowia w środowisku pracy.

Przyjęto, że wpływ każdego z wymienionych wskaźników częstości na ustalenie kategorii ryzyka dla danej grupy działalności gospodarczej jest jednakowy. Kategorię ryzyka dla grupy działalności gospodarczej ustala się na podstawie danych Głównego Urzędu Statystycznego za trzy ostatnie lata kalendarzowe, dostępne 31 stycznia danego roku, na okres nie dłuższy niż 3 lata składkowe [Rzepecki 2000, s. 16-19].

Sfera zainteresowania skutkami ekonomicznymi wypadków przy pracy jest różnorodna. Ekonomistów interesuje m.in. wpływ wypadków na wzrost obciążeń gospodarki narodowej, środowisko medyczne zaś zwraca uwagę na koszty hospitalizacji, leczenia osób poszkodowanych. Instytucje ubezpieczeniowe z kolei są zainteresowane wypłatami odszkodowań i zasiłków chorobowych, pogrzebowych oraz rent z tytułu niezdolności do pracy.

Poszkodowany na skutek wypadku przy pracy, poza poniesionym uszczerbkiem zdrowia, cierpieniem fizycznym oraz utratą pełnej zdolności zarobkowania, czego nie wyrówna żadna renta z tytułu niezdolności do pracy, traci do pewnego stopnia swoją pozycję społeczną. Uszczuplone dochody poszkodowanego na skutek zmniejszenia zarobków lub pobierania jedynie renty obniżają budżet domowy i często zmuszają członków rodziny do dodatkowej pracy zarobkowej. W przypadku śmierci poszkodowanego w następstwie wypadku przy pracy cały ciężar utrzymania domu spada na barki pozostałych członków rodziny, co z kolei może być przyczyną zmiany planów życiowych [Serafińska, Rzepecki 2004 s. 1].

\section{CEL I METODY BADAŃ}

Celem badań jest ocena przypisanej przedsiębiorstwom składki na ubezpieczenie wypadkowe przez Zakład Ubezpieczeń Społecznych w kontekście wydatków na działania prewencyjne w zakresie BHP.

W toku badań podjęto się próby zweryfikowania hipotezy badawczej, że zwiększenie składki na obowiązkowe ubezpieczenie wypadkowe powoduje wzrost wydatków na profilaktykę w zakresie BHP.

\section{CHARAKTERYSTYKA PRÓBY BADAWCZEJ}

Badaniem objęto wszystkie duże przedsiębiorstwa przemysłu spożywczego działające na terenie województwa łódzkiego, które w okresie pięcioletnim, tj. w latach 20082012 nieprzerwanie prowadziły działalność. Na podstawie danych GUS ustalono, że w województwie łódzkim w przemyśle spożywczym według stanu na 1 stycznia $2008 \mathrm{r}$. zarejestrowanych było: 
- 2103 małych przedsiębiorstw zatrudniających do 9 pracowników,

- 723 średnich przedsiębiorstw zatrudniających od 10 do 49 pracowników,

- 177 dużych przedsiębiorstw zatrudniających 50 i więcej pracowników.

Natomiast 1 stycznia 2013 r. w bazie danych GUS w przemyśle spożywczym województwa łódzkiego zarejestrowanych było:

- 1873 małych przedsiębiorstw zatrudniających do 9 pracowników,

- 644 średnich firmy zatrudniających od 10 do 49 pracowników,

- 153 dużych przedsiębiorstw zatrudniających powyżej 50 pracowników.

W wyborze obiektów badawczych zastosowano dobór celowy, będący najbardziej typowym przypadkiem doboru nielosowego. Polega on na subiektywnym doborze jednostek badanych do próby. Głównym kryterium doboru była wielkość przedsiębiorstwa oraz prowadzenie działalności gospodarczej na terenie województwa łódzkiego w sektorze spożywczym.

Początkowo planowano przeprowadzenie badań wyczerpujących [Klepacki, 1984], gdyż do badań zakwalifikowano wstępnie wszystkie duże przedsiębiorstwa działające w sektorze spożywczym w sposób nieprzerwany w latach 2008-2012. Część przedsiębiorstw jednak zaprzestała produkcji albo nastąpiły fuzje lub przejęcia. Ponadto z 36 przedsiębiorstw nie udało się uzyskać wiarygodnych danych. Jednak kompletne dane kwestionariusza ankiety zgromadzono ze 116 przedsiębiorstw przemysłu spożywczego, które stanowiły $65,5 \%$ dużych przedsiębiorstw sektora przemysłu spożywczego województwa łódzkiego według stanu na 1 stycznia 2008 r.

Do celów badawczych zastosowano podział przedsiębiorstw według rodzaju prowadzonej działalności. Wyodrębniono 6 branż:

I - przetwarzanie i konserwowanie mięsa oraz produkcja wyrobów z mięsa - 56 przedsiębiorstw,

II - produkcja wyrobów piekarskich i mącznych - badanie objęło 19 przedsiębiorstw,

III - wytwarzanie wyrobów mleczarskich - badaniem objęto 10 spółdzielni,

IV - przetwarzanie i konserwowanie owoców i warzyw - 15 przedsiębiorstw,

$\mathrm{V}$ - produkcja napojów - 7 przedsiębiorstw,

VI - produkcja pozostałych artykułów spożywczych:

- przemiału zbóż oraz produkcji pasz - 1 przedsiębiorstwo,

- kakao, czekolady i wyrobów cukierniczych - 2 przedsiębiorstwa,

- kawy i konfekcjonowanie herbaty - 1 przedsiębiorstwo,

- ryb, skorupiaków i mięczaków - 1 przedsiębiorstwo,

- dań gotowych - 2 przedsiębiorstwa,

- pozostałych artykułów spożywczych, gdzie indziej niesklasyfikowana - 2 przedsiębiorstwa.

Podział umożliwił ocenę branż pod względem wypadkowości o różnym poziomie zatrudnienia.

Materiały pochodzące $\mathrm{z}$ badań pierwotnych obejmują dane pięcioletnie z lat 20082012, które zgromadzono w kwestionariuszu pt. „Wydatki na BHP oraz świadczenia _ z tytułu wypadków przy pracy.

\section{METODY BADAŃ}

W toku badań wykorzystano m.in. narzędzia i metody statystyczne: analizę korelacji i rachunek regresji prostej. W dalszym etapie badań dotyczących określenia zależności wpływu liczby wypadków przy pracy oraz wysokości składki na ubezpieczenie wypadkowe 
na poziom ponoszonych kosztów BHP przyjęto, że w przypadku, gdy zależność korelacyjna między badanymi zmiennymi była słaba, nie był budowany model między badanymi zmiennymi. W przypadku, gdy zależność korelacyjna była co najmniej wyraźna, ale niska, szacowano model regresji liniowej, który następnie poddawano weryfikacji statystycznej. Estymacji parametrów strukturalnych modelu liniowej funkcji regresji dokonano przy wykorzystaniu klasycznej metody najmniejszych kwadratów [Witkowska 2006, s. 173], która pozwala na szacowanie parametrów strukturalnych modelu liniowego [Borkowski, Dudek, Szczesny 2003, s. 63]. Po ustaleniu postaci modelu regresji prostoliniowej między rozpatrywanymi zmiennymi dokonano oceny statystycznej skonstruowanego modelu. W ten sposób określono stopień dopasowania modelu do danych empirycznych przy wykorzystaniu miary określającej poprawność dopasowania. Analiza dopasowania modelu do danych empirycznych polegała na porównaniu wartości rzeczywistych z wartościami otrzymanymi z modelu [Witkowska 1999, s. 173]. Ze względu na charakter badań oszacowano wyłączne jednoczynnikowe modele regresji prostej, które miały na celu wskazanie siły oraz kierunku oddziaływania między badanymi zależnościami.

\section{WYNIKI BADAŃ}

Wyniki badań przedstawione w tabeli 1., dotyczące związku między poziomem kosztów na działalność profilaktyczną a wysokością składki na ubezpieczenia wypadkowe w badanych przedsiębiorstwach przemysłu spożywczego, wykazały istnienie co najmniej umiarkowanej zależności korelacyjnej między tymi zmiennymi. Poziom współczynnika determinacji wyniósł od 26,6\% w roku 2008 do 61,5\% w 2010 roku. Oznacza to, że zmienność składki na ubezpieczenie wypadkowe wyjaśniała od ponad $26 \%$ do prawie $62 \%$ zmienności poziomu kosztów na działalność profilaktyczną ogółem w badanym sektorze przedsiębiorstw przemysłu spożywczego. Również przeprowadzony test statystyczny dotyczący istotności (test t-Studenta) zmiennej objaśniającej w wyjaśnianiu zmienności zmiennej objaśnianej wykazał, że wysokość składki wypadkowej była w tym okresie istotna i nieprzypadkowa. Ponadto oszacowane modele wskazują, że (przy założeniu niezmienności innych czynników) wzrost składki o 1000 złotych wiązał się ze wzrostem kosztów na działalność profilaktyczną w badanych przedsiębiorstwach ogółem od 654 zł w 2008 roku do 894 zł w 2010 roku. Ogólnie istotne jest, że wzrost wysokości składki na ubezpieczenie wypadkowe wiązał się także ze wzrostem kosztów na profilaktykę w zakresie bezpieczeństwa i higieny pracy. Należy nadmienić, że w 2012 roku nastąpił

Tabela 1. Modele regresji liniowej kosztów na działalność profilaktyczną ogółem [tys. zł] względem wysokości składki na ubezpieczenie wypadkowe ogółem [tys. zł]

\begin{tabular}{lrrrrr}
\hline Wyszczególnienie & \multicolumn{5}{c}{ Wielkości w roku } \\
\cline { 2 - 6 } & \multicolumn{1}{c}{2008} & \multicolumn{1}{c}{2009} & \multicolumn{1}{c}{2010} & \multicolumn{1}{c}{2011} & \multicolumn{1}{c}{2012} \\
\hline Współczynnik determinacji & 0,2658 & 0,5839 & 0,6151 & 0,5793 & \multicolumn{1}{c}{0,4670} \\
Stała & 40,6433 & 32,8795 & 32,1411 & 33,4570 & 38,3060 \\
Współczynnik regresji & 0,6537 & 0,8427 & 0,8940 & 0,8851 & 0,8026 \\
Wartość statystyki t-Studenta & 6,368 & 12,5400 & 13,3800 & 12,4200 & 9,9070 \\
dla współczynnika regresji & & & &
\end{tabular}

Źródło: badanie własne, wartość krytyczna testu t-Studenta dla $n=112$ i $\alpha=0,05$ wynosi $t^{*}=1,98137$. 
spadek współczynnika regresji w oszacowanym modelu regresji prostoliniowej kosztów na działalność profilaktyczną ogółem względem wysokości składki na ubezpieczenie wypadkowe, przy jednoczesnym wzroście współczynnika korelacji między tymi zmiennymi. Może to oznaczać, że nastąpiło wzmocnienie związku między tymi zmiennymi, co można uznać za zjawisko niekorzystne dla przedsiębiorstw z tego sektora.

W dalszej części badań oceniono zależności między poziomem kosztów na działalność profilaktyczną a wysokością składki na ubezpieczenie wypadkowe w poszczególnych branżach. Pierwszą analizowaną branżą było przetwarzanie i konserwowanie mięsa oraz produkcja wyrobów z mięsa. Wyniki estymacji modeli regresji liniowej między kosztami na działalność profilaktyczną a wysokością składki na ubezpieczenia wypadkowe przedstawiono w tabeli 2.

Mając na uwadze wysokość współczynnika korelacji między badanymi zmiennymi, stwierdzono, że istnieje między nimi umiarkowana zależność korelacyjna. Z oszacowanych modeli wynika, że zmienność wysokości składki na ubezpieczenia społeczne wyjaśniała od 31,8\% w roku 2012 do 41,7\% w roku 2009 zmienności kosztów na działalność profilaktyczną w badanej branży. Test t-Studenta wskazał na istotność i nieprzypadkowość zmienności wysokości składki na ubezpieczenie wypadkowe w wyjaśnianiu zmienności poziomu kosztów na działalność profilaktyczną w branży przetwarzania i konserwowania mięsa oraz produkcji wyrobów z mięsa. Należy zauważyć, że wzrost składki na ubezpieczenie wypadkowe o 1000 zł wiązał się z przyrostem kosztów na działalność profilaktyczną na poziomie od prawie 1,3 tys. zł w roku 2008 do ponad 2 tys. zł w 2010 roku.

$\mathrm{W}$ tabeli 3. przedstawiono wyniki estymacji modeli regresji prostoliniowej kosztów na działalność profilaktyczną względem wysokości składki na ubezpieczenie wypadkowe w branży wyrobów piekarskich i mącznych.

Wyniki badań w tabeli 3. informują, że w latach 2008-2010 istniała co najmniej umiarkowana zależność korelacyjna między badanymi zmiennymi. Jednak w latach 2011-2012 zależność ta była słaba, co wskazuje na brak istotności wpływu wysokości składki na ubezpieczenie wypadkowe w objaśnianiu wysokości kosztów na działalność profilaktyczną w badanych przedsiębiorstwach z branży wyrobów piekarskich i mącznych. Ze względu na dotychczasowe wyniki dokonano estymacji modeli regresji prostoliniowej między tymi zmiennymi wyłącznie dla lat 2008-2010. Współczynnik determinacji wskazał, że w tym okresie w badanej branży zmienność wysokości składki na ubezpieczenie wypadkowe wyjaśniała od 26,6\% w roku 2008 do 83,8\% w roku 2010 zmienności kosztów na działalność profilaktyczną. Przeprowadzony test t-Studenta wykazał istotność i nieprzypadkowość wysokości składki

Tabela 2. Modele regresji liniowej kosztów na działalność profilaktyczną [tys. zł] względem wysokości składki na ubezpieczenie wypadkowe [tys. zł] w branży przetwarzania i konserwowania mięsa oraz produkcji wyrobów z mięsa

\begin{tabular}{lrrrrr}
\hline Wyszczególnienie & \multicolumn{5}{c}{ Wielkości w roku } \\
\cline { 2 - 6 } & \multicolumn{1}{c}{2008} & \multicolumn{1}{c}{2009} & \multicolumn{1}{c}{2010} & \multicolumn{1}{c}{2011} & \multicolumn{1}{c}{2012} \\
\hline Współczynnik determinacji & 0,3284 & 0,4170 & 0,4109 & 0,3786 & 0,3184 \\
Stała & 32,4113 & 24,0991 & 15,1936 & 19,5481 & 23,1728 \\
Współczynnik regresji & 1,2662 & 1,7042 & 2,0136 & 1,8107 & 1,6483 \\
Wartość statystyki t-Studenta & 5,1390 & 6,2150 & 6,1370 & 5,7360 & 5,0240 \\
dla współczynnika regresji & & & &
\end{tabular}

Źródło: badanie własne, wartość krytyczna testu t-Studenta dla $n=54$ i $\alpha=0,05$ wynosi t ${ }^{*}=2,00488$. 
Tabela 3. Modele regresji prostoliniowej kosztów na działalność profilaktyczną [tys. zł] względem wysokości składki na ubezpieczenie wypadkowe [tys. zł] w branży wyrobów piekarskich i mącznych

\begin{tabular}{lrrrrr}
\hline Wyszczególnienie & \multicolumn{5}{c}{ Wielkości w roku } \\
\cline { 2 - 6 } & \multicolumn{1}{c}{2008} & 2009 & \multicolumn{1}{c}{2010} & \multicolumn{1}{c}{2011} \\
\hline Współczynnik & 0,26609 & 0,5060 & 0,7022 & 0,81258 & 0,7235 \\
determinacji & $-30,1240$ & $-20,6744$ & $-40,5694$ & $-35,2560$ & $-45,4560$ \\
Stała & 6,0398 & 3,8816 & 5,2533 & 2,1823 & 4,2570 \\
Współczynnik regresji & & & & & 1,8564 \\
Wartość statystyki & 2,4830 & 4,1730 & 6,3310 & 1,6424 \\
t-Studenta dla & & & & & \\
współczynnika regresji & & &
\end{tabular}

Źródło: badanie własne, wartość krytyczna testu t-Studenta dla n=17 i $\alpha=0,05$ wynosi $\mathrm{t}^{*}=2,10982$.

na ubezpieczenie wypadkowe w objaśnianiu zmienności kosztów na działalność profilaktyczną analizowanej branży przedsiębiorstw. Analizując oszacowane modele regresji prostoliniowej. stwierdzono, że wzrost składki na ubezpieczenie wypadkowe o 1000 złotych związany był ze zwiększeniem kosztów na działalność profilaktyczną od niemal 3,9 tys. zł w 2009 roku do ponad 6 tys. zł w 2008 roku.

W branży wyrobów mleczarskich (tab. 4.) stwierdzono występowanie znaczącej oraz bardzo silnej zależności korelacyjnej między kosztami na działalność profilaktyczną a wysokością składki na ubezpieczenie wypadkowe.

Wysokie wartości współczynnika korelacji między badanymi zmiennymi w poszczególnych latach okresu badawczego pozwoliły na oszacowanie zależności prostoliniowej między tymi zmiennymi. Na podstawie badań stwierdzono, że wysokość składki na ubezpieczenie wpadkowe w oszacowanych modelach dla badanej branży wyjaśniała od ponad 61\% w 2008 roku do prawie 91\% w roku 2012 zmienności kosztów na działalność profilaktyczną. Ponadto zmiana wysokości składki na ubezpieczenie wypadkowe o 1000 złotych wiązała się z przyrostem kosztów na działalność profilaktyczną od 0,88 tys. zł w 2009 do 1,04 tys. zł w 2012 roku.

W przypadku branży przetwarzania i konserwowania owoców i warzyw, na podstawie przeprowadzonych badań przedstawionych w tabeli 5., stwierdzono występowanie w latach 2008-2011 umiarkowanej zależności korelacyjnej między poziomem kosztów na działalność profilaktyczną a wysokością składki na ubezpieczania wypadkowe. Jednak w roku 2012 stwierdzono występowanie słabej zależności korelacyjnej. Z tego względu dokonano estymacji modeli regresji prostoliniowej między tymi zmiennymi dla lat 2008-2011.

Tabela 4. Modele regresji prostoliniowej kosztów na działalność profilaktyczną [tys. zł] względem wysokości składki na ubezpieczenie wypadkowe [tys. zł] w branży wytwarzania wyrobów mleczarskich

\begin{tabular}{lccccc}
\hline Wyszczególnienie & \multicolumn{5}{c}{ Wielkości w roku } \\
\cline { 2 - 6 } & 2008 & 2009 & 2010 & 2011 & 2012 \\
\hline Współczynnik determinacji & 0,6125 & 0,8131 & 0,8375 & 0,8601 & 0,9092 \\
Stała & 5,5124 & 3,8583 & 0,2707 & $-0,8460$ & $-8,4123$ \\
Współczynnik regresji & 0,8894 & 0,8803 & 0,9657 & 1,0691 & 1,0385 \\
Wartość statystyki t-Studenta & 2,8110 & 4,6650 & 5,0780 & 5,5460 & 7,0770 \\
dla współczynnika regresji & & & &
\end{tabular}

Źródło: badanie własne, wartość krytyczna testu t-Studenta dla $n=9$ i $\alpha=0,05$ wynosi t* ${ }^{*}=2,26216$. 
Tabela 5. Modele regresji prostoliniowej kosztów na działalność profilaktyczną [tys. zł] względem wysokości składki na ubezpieczenie wypadkowe [tys. zł] w branży przetwarzania i konserwowania owoców i warzyw

\begin{tabular}{lrrrrr}
\hline Wyszczególnienie & \multicolumn{5}{c}{ Wielkości w roku } \\
\cline { 2 - 6 } & \multicolumn{1}{c}{2008} & \multicolumn{1}{c}{2009} & \multicolumn{1}{c}{2010} & \multicolumn{1}{c}{2011} & \multicolumn{1}{c}{2012} \\
\hline Współczynnik determinacji & 0,1853 & 0,2092 & 0,3828 & 0,1955 & 0,062 \\
Stała & 30,5196 & 34,8961 & 27,6388 & 32,9837 & 31,2672 \\
Współczynnik regresji & 0,7995 & 0,8053 & 1,1294 & 0,7178 & 0,8236 \\
Wartość statystyki t-Studenta & 1,7200 & 1,8550 & 2,8400 & 1,7780 & 1,2470 \\
dla współczynnika regresji & & & &
\end{tabular}

Źródło: badanie własne, wartość krytyczna testu t-Studenta dla $n=13$ i $\alpha=0,05$ wynosi t ${ }^{*}=2,16037$.

W branży przetwarzania i konserwowania owoców i warzyw zmienność składki na ubezpieczenie wypadkowe wiązała się ze zmiennością kosztów na działalność profilaktyczną od ponad $18,5 \% \mathrm{w}$ roku 2008 do ponad 19,5\% w roku 2011. Przeprowadzony test statystyczny potwierdził, że wysokość składki na ubezpieczenie wypadkowe była istotna i nieprzypadkowa w objaśnianiu poziomu kosztów na działalność profilaktyczną badanej branży przedsiębiorstw. W związku z tym na podstawie oszacowanych modeli przy założeniu niezmienności pozostałych czynników można było uznać, że zwiększenie składki na ubezpieczenie wypadkowe o 1000 złotych wiązało się ze wzrostem kosztów na działalność profilaktyczną w badanej branży przedsiębiorstw od 0,72 tys. zł w 2011 roku do prawie 1,13 tys. zł w roku 2010.

W przypadku branży produkcji napojów (tab. 6.) stwierdzono istnienie bardzo silnego związku korelacyjnego między wysokością składki na ubezpieczenie wypadkowe a kosztami na działalność profilaktyczną. Oszacowane modele regresji prostoliniowej kosztów na działalność profilaktyczną względem wysokości składki na ubezpieczenie wypadkowe wskazały, że zmienność wysokości tej składki związana była z wyjaśnieniem zmienności kosztów na działalność profilaktyczną od 70,9\% w roku 2012 do ponad 97,1\% w roku 2009.

Również test t-Studenta wskazał na wysoki poziom istotności i nieprzypadkowości zmiennej objaśniającej w wyjaśnianiu zmienności zmiennej objaśnianej. Na podstawie wyników badań stwierdzono, że zmiana składki na ubezpieczenie wypadkowe o 1000 złotych związana była ze wzrostem kosztów na działalność profilaktyczną w przedziale od 0,56 tys. zł w roku 2008 do blisko 0,8 tys. zł w 2010 roku.

W ostatniej analizowanej branży, tj. produkcji pozostałych artykułów spożywczych (kakao, czekolady, kawy, ryb itd.), na podstawie przeprowadzonych badań, przedstawionych w tabeli 7. stwierdzono, że istnieje bardzo silna zależność korelacyjna między wysokością

Tabela 6. Modele regresji prostoliniowej kosztów na działalność profilaktyczną [tys. zł] względem wysokości składki na ubezpieczenie wypadkowe [tys. zł] w branży produkcji napojów

\begin{tabular}{lrrrrr}
\hline Wyszczególnienie & \multicolumn{5}{c}{ Wielkości w roku } \\
\cline { 2 - 6 } & \multicolumn{1}{c}{2008} & \multicolumn{1}{c}{2009} & \multicolumn{1}{c}{2010} & \multicolumn{1}{c}{2011} \\
\hline Współczynnik determinacji & 0,9173 & 0,9716 & 0,9537 & 0,9077 & 0,7086 \\
Stała & 40,4554 & 37,1655 & 44,5160 & 54,7672 & 88,0094 \\
Współczynnik regresji & 0,5632 & 0,7548 & 0,7976 & 0,7555 & 0,6354 \\
Wartość statystyki t-Studenta & 9,9940 & 17,5500 & 13,6200 & 9,4100 & 4,6790 \\
dla współczynnika regresji & & &
\end{tabular}

Źródło: badanie własne, wartość krytyczna testu t-Studenta dla n=5 i $\alpha=0,05$ wynosi $\mathrm{t}^{*}=2,57058$. 
Tabela 7. Modele regresji prostoliniowej kosztów na działalność profilaktyczną [tys. zł] względem wysokości składki na ubezpieczenie wypadkowe [tys. zł] w branży produkcji pozostałych artykułów spożywczych

\begin{tabular}{lrrrrr}
\hline \multirow{2}{*}{ Wyszczególnienie } & \multicolumn{5}{c}{ Wielkości w roku } \\
\cline { 2 - 6 } & 2008 & 2009 & \multicolumn{1}{c}{2010} & \multicolumn{1}{c}{2011} & \multicolumn{1}{c}{2012} \\
\hline Współczynnik determinacji & 0,9977 & 0,9989 & 0,9981 & 0,9980 & 0,9965 \\
Stała & 2,6015 & 1,4443 & 1,3238 & $-1,1929$ & $-3,7022$ \\
Współczynnik regresji & 1,1680 & 1,2937 & 1,2390 & 1,4918 & 1,5315 \\
Wartość statystyki t-Studenta & 41,9100 & 60,4900 & 46,9200 & 45,4700 & \multirow{2}{*}{33,8500} \\
dla współczynnika regresji & & & & \\
\hline
\end{tabular}

Źródło: badanie własne, wartość krytyczna testu t-Studenta dla $n=4$ i $\alpha=0,05$ wynosi $\mathrm{t}^{*}=2,77645$.

składki na ubezpieczenie wypadkowe a wysokością kosztów na działalność profilaktyczną ponoszonych przez przedsiębiorstwa $z$ tej branży.

Z oszacowanych modeli przedstawionych w tabeli 7. wynika, że zmienność wysokości składki na ubezpieczenie wypadkowe wyjaśniała ponad 99\% zmienności kosztów na działalność profilaktyczną, co może wskazywać na niemal deterministyczny rodzaj zależności między badanymi zmiennymi. Oznacza to, że wydatki na działalność profilaktyczną są wyznaczane na podstawie składki na ubezpieczenia wypadkowe. Ponadto wyniki testu t-Studenta i testu F-Snedecora wskazały na statystyczną istotność i nieprzypadkowość składki wypadkowej w objaśnianiu zmienności kosztów na działalność profilaktyczną przedsiębiorstw z branży produkcji pozostałych artykułów spożywczych. Na podstawie oszacowanych modeli można było stwierdzić, że zwiększenie o 1000 złotych składki na ubezpieczenie wypadkowe spowodowało, przy założeniu niezmienności pozostałych czynników, wzrost kosztów na działalność profilaktyczną od niemal 1,17 tys. zł w 2008 roku do ponad 1,53 tys. zł w roku 2012.

Na podstawie wyników badań należy stwierdzić, że hipotezę badawczą potwierdzono.

\section{PODSUMOWANIE}

Przeprowadzone badania wykazały, że wraz ze wzrostem wysokości składki na ubezpieczenie wypadkowe wzrastał poziom kosztów prewencji w zakresie bezpieczeństwa i higieny pracy w przedsiębiorstwach przemysłu spożywczego. Ponadto stwierdzono, że w przypadku wszystkich badanych branż zależność ta potwierdziła się, a siła tego związku zależała od branży.

Ustalono, że wysokość odprowadzanej składki na ubezpieczenie wypadkowe wpływała dodatnio na poziom kosztów BHP w badanym sektorze.

Pozytywnym zjawiskiem jest to, że przedsiębiorstwa w odpowiedzi na rosnącą liczbę wypadków przy pracy i związane z tym wydatki wynikające z odprowadzanej składki na ubezpieczenie wypadkowe próbowały zapobiegać następnym wypadkom poprzez zwiększanie kosztów działań w zakresie bezpieczeństwa i higieny pracy. Jednakże z drugiej strony wzrost tych kosztów w latach 2008-2012 w badanym sektorze był niewystarczający. Koszty BHP wzrosły o 2,5\%, a koszty składek na ubezpieczenie wypadkowe o 49\%. W związku z tym należy stwierdzić, że koszty BHP są w dalszym ciągu zbyt niskie i na ogół nie dają oczekiwanych efektów. Co ważne, przyrost kosztów na działalność profilaktyczną nie ma charakteru wyprzedzającego względem zmian skali wypadków przy pracy. Można zatem uznać, że sytuację w tym zakresie należałoby zmienić w taki sposób, żeby wyprzedzająco 
zwiększać koszty na działalność profilaktyczną, tak aby efekty w postaci zmniejszania liczby wypadków przy pracy były osiągnięte.

Odpowiednie warunki pracy i działalność zapobiegawcza w zakresie BHP mają bezpośredni wpływ na zmniejszenie liczby wypadków przy pracy i chorób zawodowych. Służą zatem ochronie zdrowia i życia osób zatrudnionych w zakładach pracy. Zmniejszenie liczby wypadków przy pracy wpływa na obniżenia składki na ubezpieczenie wypadkowe, a tym samym przyczynia się do poprawy wyniku finansowego przedsiębiorstw.

\title{
LITERATURA
}

Barwicka Alicja, 2011: Wypadki przy pracy, choroby zawodowe i zwiazane z prace-występowanie i prewencja, „ZUS, Prewencja i Rehabilitacja”, Warszawa, s. 1-3.

Borkowski Bolesław, Hanna Dudek, Wiesław Szczesny, 2003: Ekonometria. Wybrane zagadnienia, Wydawnictwo Naukowe PWN, Warszawa, s. 26-63.

GUS, 2007: Polska Klasyfikacja działalności, Warszawa.

Klepacki Bogdan, 1984: Wybór próby w badaniach ekonomiczno-rolniczych, Wydaw. SGGW-AR, Warszawa. Rozporzadzenie Ministra Pracy i Polityki Społecznej z dnia 29 listopada 2002 r. w sprawie różnicowania stopy procentowej składki na ubezpieczenie społeczne z tytulu wypadków przy pracy i chorób zawodowych w zależności od zagrożeń zawodowych i ich skutków. Dz.U. nr 200, poz. 1692.

Rzepecki Jan, 2000: Model zróżnicowanej składki na społeczne ubezpieczenie wypadkowe „Bezpieczeństwo Pracy", Warszawa, s. 16-19.

Serafińska Anna, Jan Rzepecki, 2004: Koszty wypadków przy pracy w Polsce, „ZUS, Prewencja i rehabilitacja", Warszawa, s. 1-3.

Ślawska Grażyna, 2006: Prawne aspekty wypadków przy pracy, „ZUS Prewencja i rehabilitacja”, Warszawa, s. 11-21.

Traktat ustanawiający Wspólnotę Europejska, Dz.Urz. UE 2006 C 321E.

Witkowska Dorota, 2006: Podstawy ekonometrii i teorii prognozowania, Podręcznik z przykładami i zadaniami, Wydawnictwo Oficyna Ekonomiczna, Kraków, s. 54-83.

Witkowska Dorota (red.), 1999: Metody statystyczne w zarządzaniu, Politechnika Łódzka, Łódź, s. 173.

\section{Anetta Zielińska}

\section{EVALUATION OF BENEFITS BETWEEN ACCIDENTAL INSURANCE AND PROFILES OF HEALTH AND SAFETY IN FOOD INDUSTRY COMPANIES}

\begin{abstract}
Summary
The paper makes an attempt to evaluate the dependence between the level of the coverage of the accident insurance and the level of the costs of the work safety regulation prevention that does not include the cost of the contribution. It highlights the dependence of the costs/expenditure of the contribution of the accident insurance payed by the employers and the costs/expenditure of the employers in the range of the implementation of objectives of accident prevention at food industry companies in the Eódź region. In the course of the study the models of rectilinear costs regression on the prevention activity in regard to the level of the contribution of the accident insurance have been evaluated. The models indicated the existence of added/positive dependence between the variables.
\end{abstract}

Adres do korespondencji: Dr Anetta Zielińska

Uniwersytet Jana Kochanowskiego w Kielcach, Filia w Piotrkowie Trybunalskim Wydział Nauk Społecznych, Katedra Zarządzania ul. J. Słowackiego 114/118, 97-300 Piotrków Tryb. tel.601-669-317, e-mail: a.zielinska@unipt.pl 